\title{
Cholesteryl ester transfer protein TaqlB polymorphism and its association with serum lipid levels and longevity in Chinese Bama Zhuang population
}

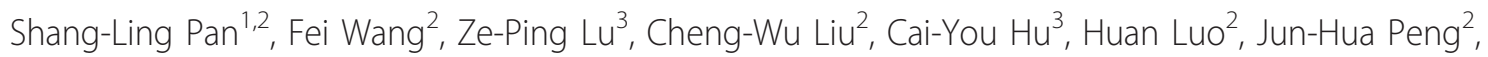
Xiao-Qiu Luo², Guo-Fang Pang ${ }^{3}$, Shao-Hua Lu², Hua-Yu Wu², Ling-Jin Huang ${ }^{2}$ and Rui-Xing Yin ${ }^{*}$

\begin{abstract}
Background: TaqIB polymorphism in the cholesteryl ester transfer protein (CETP) gene has been reported to be associated with serum high-density lipoprotein cholesterol (HDL-C) levels and longevity in several populations, but controversial results also arose probably due to racial/ethnic diversity. Bama is a remote and mountainous county located in the northwest of Guangxi, People's Republic of China, which has been well known for its longevity for centuries. The current study was to investigate the possible association of CETP TaqIB polymorphism with serum lipid levels and longevity in the Bama Zhuang population.
\end{abstract}

Methods: The CETP TaqIB genotypes were determined by polymerase chain reaction and restriction fragment length polymorphism in 523 long-lived inhabitants (long-lived group, LG; aged 90-107 years) and 498 healthy controls without longevity family history (non-long-lived group, non-LG; aged 40-69 years) residing in Bama County.

Results: The levels of total cholesterol (TC), high-density lipoprotein cholesterol (HDL-C), and low-density lipoprotein cholesterol (LDL-C) were higher but TG, HDL-C/LDL-C ratio and the prevalence of dyslipidemia were lower in $L G$ than in non-LG $(P<0.001$ for all). There were no differences in the allelic and genotypic frequencies between the two groups $(P>0.05)$. Serum HDL-C levels and HDL-C/LDL-C ratio in LG were different among the genotypes $(P<0.01$ for each), the subjects with B2B2 and B1B2 genotyes had higher HDL-C levels and HDL-C/LDL$C$ ratio than the subjects with B1B1genotye, whereas the levels of TC and HDL-C in non-LG were different among/ between the genotypes $(P<0.01$ for each), the B2 allele carriers had lower TC and higher HDL-C levels than the B2 allele noncarriers. Serum TG and HDL-C levels and HDL-C/LDL-C ratio were correlated with genotypes in LG, whereas serum TC and HDL-C levels were associated with genotypes in non-LG $(P<0.05-0.001)$.

Conclusions: The association of CETP TaqIB polymorphism and serum lipid profiles is different between LG and non-LG in the Chinese Bama Zhuang population. CETP TaqIB polymorphism might be one of the longevity-related genetic factors in this population.

\section{Introduction}

Cholesterol plays an essential physiological role in humans. It is mainly synthesized and esterified by the liver and then is secreted from the liver into plasma as very low density lipoprotein (VLDL), which gets converted to low

\footnotetext{
* Correspondence: yinruixing@yahoo.com.cn

'Department of Cardiology, Institute of Cardiovascular Diseases, the First Affiliated Hospital, Guangxi Medical University, 22 Shuangyong Road,

Nanning 530021, Guangxi, People's Republic of China

Full list of author information is available at the end of the article
}

density lipoprotein (LDL). In contrast, reverse cholesterol transport (RCT) mediates the conveyance of free unesterified cholesterol mobilized from peripheral cells and destined for disposal by the liver. In this process, cholesteryl ester transfer protein (CETP), a 74-kDa hydrophobic glycoprotein, facilitates the transfer of cholesterol ester from high density lipoprotein (HDL) to apolipoprotein (Apo) B-containing lipoproteins including VLDL and LDL, for disposal via the LDL receptor pathway in the liver, and of 
triglyceride (TG) in the opposite direction in plasma [1,2]. Remarkably, these rationales indicate that CETP plays a significant role in the modulation of cholesterol.

In humans, CETP is expressed predominantly in the liver, spleen, and adipose tissue [1]. Detectable levels of CETP can also be seen in the small intestine, adrenal glands, heart, kidneys, or skeletal muscle [3]. The gene encoding CETP consists of 16 exons and 15 introns encompassing $25 \mathrm{~kb}$ on chromosome 16q12-21 adjacent to the lecithin-cholesterol acyltransferase gene [4]. To date, a number of common polymorphisms and rare variants at the CETP gene locus, such as I405V, D442G, I14A, A373P, R451Q, promoter polymorphism (Y629A/ C, Y1337C/T and Y971G/A), which cause depletion of CETP activity and consequently high high-density lipoprotein cholesterol (HDL-C) in plasma, have been described across populations [5-8]. One of these common polymorphisms is TaqIB, a silent base change affecting the 277th nucleotide in the first intron of the CETP gene [4]. The B2 allele, absence of the TaqI restriction site, has been found to be associated with elevated plasma HDL-C level and reduced plasma CETP mass and activity and coronary heart disease (CHD) risk [9-12], and accordingly to be associated with longer life expectancy $[13,14]$. This hypothesis is further supported by the fact that high HDL-C levels are often observed in healthy elderly aged 85 and above $[13,15]$. However, inconsistent findings also arose in different studies, e.g., a positive association of HDL-C levels with increased CHD risk has been reported [16]; not all CETP deficiencies with high HDL-C levels are correlated with longevity [17]. These controversial results suggest that the roles of CETP gene variations in longevity appear much more complex than expected and need further elucidation.

Bama is a remote and mountainous county located in the northwest of Guangxi, People's Republic of China. It has been well known for its longevity for centuries. The population size and centenarian rate in Bama County are around 240,000 and 30/100,000 respectively, according to the National Population Census of China in the past decades $[18,19]$. Although a number of studies involving natural environment, dietary habit, socioeconomic status and genetic background have been conducted for decades [19-22], the underlying mechanisms of the longevity in this county are still unknown. Genetically, the majority (> 85\%) of the inhabitants living in Bama County belong to the north branch of Zhuang ethnic group. Zhuang is the largest minority in China with a total population of 15 millions [23,24]. Long-term geographic and social isolation as well as inbreeding result in both cultural and genetic homogeneity of Bama Zhuang branch, and therefore Bama Zhuang has become a useful subgroup for population genetic studies. We have initiated the Bama Longevity Genetic Study (BLGS) since late 1998. Several genetic polymorphisms such as human leukocyte antigen (HLA), ApoE, p53, and transforming growth factor- $\beta 1$ (TGF- $\beta 1$ ) genes and the haplotypes of mitochondria DNA [19,25-29] have been shown difference between long-lived group (LG) and non-long-lived group (nonLG), indicating that Bama long-lived individuals may have favorable genetic background for their survivals. Therefore, the aim of the present study was to determine the TaqIB polymorphism of CETP gene and its association with serum lipid levels and longevity in the Chinese Bama Zhuang population.

\section{Materials and methods Study population}

A total of 523 long-lived subjects (339 females and 184 males, LG) with exceptional longevity residing in Bama County, Guangxi, People's Republic of China were recruited to participate in the study, which was conducted from 2008 to 2011. The ages of the subjects ranged from 90 to 107 years, with an average age of $93.38 \pm$ 3.09 years. The ages were defined by dates of birth as stated on identity cards. During the same period, a total of 498 healthy participants (253 males and 245 females, non-LG) without longevity family history were also randomly selected from the same area. The average age of the participants was $53.12 \pm 8.86$ years (range, 40-69 years). All study subjects were unrelated and belong to Zhuang ethnic group. They have been living in Bama rural area and doing farm work lifelong. All subjects were essentially healthy and had no evidence of any chronic illness, including hepatic, renal, or thyroid. The participants with a history of myocardial infarction, stroke, diabetes were also excluded. The participants were not taking medications known to affect serum lipid levels such as statins or fibrates, beta-blockers, diuretics, or hormones. The current study was approved by the Ethics Committee of Guangxi Medical University. Informed consent was obtained from all subjects after they received a full explanation of the study.

\section{Epidemiological survey}

Information on demography and lifestyle factors was collected with standardized questionnaires. The physical examination included blood pressure, body height, body weight, waist circumference, and body mass index (BMI) was calculated as weight in kilograms divided by the square of height in meters $\left(\mathrm{kg} / \mathrm{m}^{2}\right)$. Sitting blood pressure was obtained 3 times, using a standard mercury sphygmomanometer with the subject resting for at least 5 minutes, and the average of the 3 measurements was used for the level of blood pressure. Systolic blood pressure was determined by the first Korotkoff sound; and diastolic blood pressure, by the fifth Korotkoff sound. Hypertension was defined as an average systolic blood pressure of 
$140 \mathrm{mmHg}$ or greater and an average diastolic blood pressure of $90 \mathrm{mmHg}$ or greater, and/or self-reported pharmacological treatment for hypertension within the 2 weeks prior to the interview [30]. Normal weight, overweight, and obesity were defined as BMI $<24,24$ to 28 , and $>28 \mathrm{~kg} / \mathrm{m}^{2}$, respectively [31].

\section{Biochemical analysis}

A venous blood sample of $8 \mathrm{~mL}$ was drawn from each subject after an overnight fasting. $4 \mathrm{~mL}$ of the sample was collected in a glass tube for serum lipid determination. The remaining sample was transferred to a tube with anticoagulant solution $(4.80 \mathrm{~g} / \mathrm{L}$ citric acid, $14.70 \mathrm{~g} / \mathrm{L}$ glucose, and $13.20 \mathrm{~g} / \mathrm{L}$ trisodium citrate) for DNA extraction. The levels of serum total cholesterol (TC), TG, HDL-C, and LDL-C in samples were determined by enzymatic methods with commercially available kits, Tcho-1, TGLH (Randox Laboratories Ltd, Crumlin, Antrim, United Kingdom), Cholestest N HDL, and Cholestest LDL (Daiichi Pure Chemicals Co, Ltd., Tokyo, Japan), respectively. All determinations were performed by standard automated methods with a biochemical analyzer (Type 7170A; Hitachi Ltd, Tokyo, Japan) at the Clinical Science Experiment Center of the First Affiliated Hospital, Guangxi Medical University. The normal ranges of serum TC, TG, HDL-C, and LDL-C levels in the Center were 3.10-5.17, 0.56-1.70, 0.91-1.81, and 1.70-3.20 $\mathrm{mmol} / \mathrm{L}$, respectively. The individuals with TC $>5.17 \mathrm{mmol} / \mathrm{L}$ and/or TG $>1.70 \mathrm{mmol} / \mathrm{L}$ were defined as hyperlipidemic [32].

\section{DNA amplification and genotyping}

Genomic DNA was isolated from peripheral blood leukocytes by standard methods [33]. Genotyping of the CETP TaqIB was performed as described previously [34] basing on the protocol introduced by Fumeron et al. [35]. Briefly, a 535 bp fragment in intron 1 of the CETP gene was amplified by polymerase chain reaction (PCR), with use of the following primers: F: 5'-CACTAGCCCAGAGAGAGGAGTGCC-3' and R: 5'-CTGAGCCCAGCCGCACACTAA-3'. (Sangon Biotech Co., Ltd., Shanghai, People's Republic of China). PCR was performed in a volume of $20 \mu \mathrm{L}$ containing $200 \mathrm{ng}$ of genomic DNA, plus $10 \mu \mathrm{L}$ of Taq MasterMix (Beijing CoWin Bioscience Co., Ltd. People's Republic of China), $6.25 \mu \mathrm{M}(1.0 \mu \mathrm{L})$ of each primer, $7 \mu \mathrm{L} \mathrm{ddH}_{2} \mathrm{O}$ and $1 \mathrm{U}$ of DNA polymerase (Takara Biotechnology Co, Ltd, Dalian, People's Republic of China). The cycle profile was as follows: predenaturation at $94^{\circ} \mathrm{C}$ for $2 \mathrm{~min}$, followed by 30 cycles of denaturation at $94^{\circ} \mathrm{C}$ for $30 \mathrm{~s}$, annealing at $63^{\circ} \mathrm{C}$ for $30 \mathrm{~s}$, and extension at $72^{\circ} \mathrm{C}$ for $30 \mathrm{~s}$, with a final extension at $72^{\circ} \mathrm{C}$ for $5 \mathrm{~min}$. The PCR products $(8 \mu \mathrm{L})$ were digested with TaqI (0.2 U) restriction endonuclease (Takara Biotechnology Co, Ltd, Dalian, People's Republic of China) at $65^{\circ} \mathrm{C}$ for $4 \mathrm{~h}$, and the fragments were separated by electrophoresis in a $2 \%$ agarose gel for $45 \mathrm{~min}$ at $80 \mathrm{~V}$. The target DNA fragments were 174- and 361-bp for the B1 allele and $535 \mathrm{bp}$ for the B2 allele. The genotypes were identified and named according to the presence or absence of the enzymatic restriction sites, i.e. bands at 535-, 361-, and 174-bp for B1B2 heterozygotic genotype, 361- and 174-bp for B1B1 homozygotic genotype, and 535 bp for B2B2 homozygotic genotype. Laboratory technicians were masked to clinical and biochemical data.

\section{Statistical analyses}

Levels of the quantitative variables are presented as mean \pm SD (serum TG levels are presented as medians and interquartile ranges). Hardy-Weinberg equilibrium was computed for the expected genotype distribution. Allelic and genotypic frequencies were calculated directly. Comparison of mean values of general characteristics between study groups was performed with the student unpaired $t$ test and One-way ANOVA test. The statistical evaluation for the categorical variables was based on the calculation of the chi-square and Fisher's exact criteria. The association of CETP TaqIB genotypes with serum lipid variables was tested by analysis of covariance. In order to assess the association of serum lipid levels with genotypes $(\mathrm{B} 1 \mathrm{~B} 1=1, \mathrm{~B} 1 \mathrm{~B} 2=2$ and $\mathrm{B} 2 \mathrm{~B} 2=$ 3 ), multivariable linear regression analyses with stepwise modeling were also performed in the combined population of LG and non-LG, LG, non-LG; respectively. All tests were two-sided and $P$-values of 0.05 were considered significant. Data were analyzed using the statistical software package SPSS 13.0 (SPSS Inc, Chicago, IL).

\section{Results}

\section{General characteristics and serum lipid levels}

A summary of demographic, clinical, and biochemical characteristics of LG and non-LG is provided in Table 1. BMI was lower in LG as compared to non-LG $(P<0.001)$. The levels of systolic blood pressure and diastolic blood pressure were significantly higher in LG than in non-LG $(P<0.001$ for all). The levels of TC, HDL-C, and LDL-C were markedly higher, while TG, HDL-C/LDL-C ratio as well as the prevalence of dyslipidemia were lower in LG as compared with non-LG $(P<0.001$ for all).

\section{Genotypic and allelic frequencies}

The CETP TaqIB genotype and allele frequencies are shown in Table 2. The dominant allele was B1, and the dominant genotypes were B1B2 and B1B1 in both groups. Homozygotic B2B2 genotype only accounted for approximately $10 \%$ in the studied participants. No significant difference was observed in the distribution of genotypes and alleles between the two groups (both $P>0.05$ ), albeit the frequency of B2 allele was slightly higher in the longevity group as compared with the counterparts. 
Table 1 Clinical characteristics and serum lipid profiles between LG and non-LG

\begin{tabular}{|c|c|c|c|c|}
\hline Paramenter & LG $(n=523)$ & non-LG $(n=498)$ & $t\left(\chi^{2}\right)$ & $P$ \\
\hline Age (years) & $93.38 \pm 3.06$ & $53.12 \pm 8.86$ & 96.088 & 0.000 \\
\hline Gender (M/F) & 184/339 & $253 / 245$ & 25.428 & 0.000 \\
\hline Body mass index $\left(\mathrm{kg} / \mathrm{m}^{2}\right)$ & $20.22 \pm 3.52$ & $22.14 \pm 3.67$ & -8.521 & 0.000 \\
\hline Systolic blood pressure $(\mathrm{mmHg})$ & $166.14 \pm 28.04$ & $131.31 \pm 20.23$ & 22.844 & 0.000 \\
\hline Diastolic blood pressure $(\mathrm{mmHg})$ & $89.33 \pm 13.48$ & $85.24 \pm 11.43$ & 5.240 & 0.000 \\
\hline Total cholesterol (mmol/L) & $5.13 \pm 1.01$ & $4.87 \pm 0.96$ & 4.177 & 0.000 \\
\hline Triglyceride (mmol/L) & $0.97(0.47)$ & $1.08(0.86)$ & -3.256 & 0.001 \\
\hline $\mathrm{HDL}-\mathrm{C}(\mathrm{mmol} / \mathrm{L})$ & $1.60 \pm 0.35$ & $1.51 \pm 0.29$ & 4.698 & 0.000 \\
\hline LDL-C (mmol/L) & $3.04 \pm 0.87$ & $2.69 \pm 0.89$ & 6.427 & 0.000 \\
\hline HDL-C/LDL-C ratio & $0.57 \pm 0.24$ & $0.67 \pm 0.59$ & -3.466 & 0.001 \\
\hline Dyslipidemia [n (\%)] & $66(12.62)$ & $94(18.88)$ & -7.555 & 0.000 \\
\hline
\end{tabular}

HDL-C, high-density lipoprotein cholesterol; LDL-C, low-density lipoprotein cholesterol. The value of triglyceride was presented as median (interquartile range), the difference between the two groups was determined by the Wilcoxon-Mann-Whitney test.

\section{Genotypes and serum lipid levels}

As shown in Table 3, the levels of HDL-C and the ratio of HDL-C to LDL-C in LG were different among the genotypes $(P<0.01$ for each), the subjects with B2B2 and B1B2 genotyes had higher HDL-C levels and HDL$\mathrm{C} / \mathrm{LDL}-\mathrm{C}$ ratio than the subjects with $\mathrm{B} 1 \mathrm{~B} 1$ genotye, whereas the levels of TC and HDL-C in non-LG were different among/between the genotypes $(P<0.01$ for each), the B2 allele carriers had lower TC and higher HDL-C levels than the B2 allele noncarriers. When the association of CETP TaqIB polymorphism and serum lipid levels was stratified by gender, we found that serum TC, TG, and HDL-C levels in the combined population were different among the genotypes in males $(P<0.05-0.001)$, and HDL-C and LDL-C levels were different among the genotypes in females $(P<0.01$ and $P<0.05$; respectively; Table 4). Serum HDL-C levels in LG were different among the genotypes in males $(P<$ 0.05 ) but not in females (Table 5). Serum HDL-C levels in non-LG were different among the genotypes in males $(P<0.001)$, and TC, HDL-C and LDL-C levels were different among the genotypes in females $(P<0.05-0.001$; Table 6).

\section{Correlation between serum lipid parameters and genotypes}

Multiple linear regression analysis showed that serum TG and HDL-C levels and HDL-C/LDL-C ratio were correlated with genotypes in LG, whereas serum TC and
HDL-C levels were associated with genotypes in non-LG $(P<0.05-0.001$; Table 7).

\section{Discussion}

TaqIB is one of the common polymorphisms of the CETP gene. In the current study, the overall frequency of B2 allele was 0.372 (0.384 in LG and 0.345 in non-LG), similar to our previous finding in Hei Yi Zhuang, another Zhuang subgroup resides in Napo, a county bordering northwest Vietnam $[34,36]$, and to the result from different populations, such as Han Chinese (0.39), Vietnamese (0.34), and Korean (0.36) [37-39], but lower than that in Caucasians (0.40-0.64) $[14,40]$, Jewishes and Japaneses $[17,41,42]$. The considerable high frequency of B2 mutation across populations worldwide appears to imply that the origin of $\mathrm{B} 2$ can at least be traced back long before the differentiation of major ethnic groups for some selective reasons. We did not observe significant difference in genotypic and allelic frequencies of CETP TaqIB polymorphism between the two groups; this was in agreement with those of the Japanese centenarian study $[13,17]$. However, there was a trend that the frequencies of $\mathrm{B} 1$ allele and $\mathrm{B} 1 \mathrm{~B} 1$ genotype in long-lived individuals was slightly lower than those in non-long-lived subjects, or conversely, the B2 allele tended to enrich in the elderly old. This observation seems to imply that the evolution of B2 allele may be favorable for the survivals of modern human beings whose living environment and dietary structure have been changing tremendously, at least in Bama area.

Table 2 Genotype and allele frequencies of the CETP TaqIB polymorphism in LG and non-LG [n (\%)]

\begin{tabular}{ccccccc}
\hline Groups & $\mathbf{n}$ & \multicolumn{3}{c}{ Genotype } & & Allele \\
\cline { 3 - 5 } & & B1B1 & B1B2 & B2B2 & & B2 \\
\hline LG & 523 & $187(35.8)$ & $270(51.6)$ & $66(12.6)$ & $644(61.6)$ & $402(38.4)$ \\
Non-LG & 498 & $206(41.4)$ & $240(48.2)$ & $52(10.4)$ & $652(65.5)$ & $344(34.5)$ \\
$\chi^{2}$ & - & & 3.734 & & 3.336 & 0.068 \\
$P$ & - & & 0.155 & & \\
\hline
\end{tabular}


Table 3 Comparison of serum lipid levels among the genotypes between the two groups

\begin{tabular}{|c|c|c|c|c|c|c|c|}
\hline Group & Genotype & $\mathbf{n}$ & $\begin{array}{c}\text { TC } \\
(\mathrm{mmol} / \mathrm{L})\end{array}$ & $\begin{array}{c}\text { TG } \\
(\mathrm{mmol} / \mathrm{L})\end{array}$ & $\begin{array}{c}\mathrm{HDL}-\mathrm{C} \\
(\mathrm{mmol} / \mathrm{L})\end{array}$ & $\begin{array}{c}\text { LDL-C } \\
(\mathrm{mmol} / \mathrm{L})\end{array}$ & $\begin{array}{l}\text { HDL-C } \\
\text { /LDL-C }\end{array}$ \\
\hline \multirow[t]{3}{*}{ LG } & B1B1 & 187 & $5.16 \pm 1.00$ & $1.03(0.59)$ & $1.54 \pm 0.31^{b}$ & $3.11 \pm 0.84^{b}$ & $0.53 \pm 0.17$ \\
\hline & B1B2 & 270 & $5.09 \pm 1.02$ & $0.95(0.44)$ & $1.63 \pm 0.37^{a}$ & $3.01 \pm 0.89^{b}$ & $0.60 \pm 0.26$ \\
\hline & B2B2 & 66 & $5.17 \pm 0.99$ & $0.97(0.41)$ & $1.67 \pm 0.35^{\mathrm{a}}$ & $2.99 \pm 0.88^{b}$ & $0.62 \pm 0.28$ \\
\hline$F$ & - & - & 0.283 & 3.845 & 4.868 & 0.867 & 6.592 \\
\hline \multirow[t]{3}{*}{ P } & - & - & 0.753 & 0.146 & 0.008 & 0.421 & 0.001 \\
\hline & B1B1 & 187 & $5.16 \pm 1.00$ & $1.03(0.59)$ & $1.54 \pm 0.31$ & $3.11 \pm 0.84$ & $0.53 \pm 0.17$ \\
\hline & B1B2/B2B2 & 336 & $5.11 \pm 1.01$ & $0.95(0.43)$ & $1.64 \pm 0.37$ & $3.00 \pm 0.89$ & $0.60 \pm 0.27$ \\
\hline F & - & - & 0.247 & -1.779 & 10.279 & 1.785 & 12.432 \\
\hline$P$ & - & - & 0.620 & 0.075 & 0.001 & 0.182 & 0.000 \\
\hline \multirow[t]{3}{*}{ Non-LG } & B1B1 & 206 & $4.79 \pm 0.96$ & $1.12(0.84)$ & $1.45 \pm 0.29$ & $2.64 \pm 0.90$ & $0.70 \pm 0.82$ \\
\hline & B1B2 & 240 & $4.92 \pm 0.93$ & $1.04(0.84)$ & $1.53 \pm 0.28^{a}$ & $2.76 \pm 0.90$ & $0.64 \pm 0.36$ \\
\hline & B2B2 & 52 & $4.95 \pm 1.09$ & $1.27(1.11)$ & $1.64 \pm 0.28^{\mathrm{a}}$ & $2.53 \pm 0.81$ & $0.74 \pm 0.33$ \\
\hline$F$ & - & - & 1.288 & 3.636 & 10.681 & 1.950 & 0.875 \\
\hline \multirow[t]{3}{*}{ P } & - & - & 0.277 & 0.162 & 0.000 & 0.143 & 0.418 \\
\hline & B1B1 & 206 & $4.79 \pm 0.96$ & $1.12(0.84)$ & $1.45 \pm 0.29$ & $2.64 \pm 0.90$ & $0.70 \pm 0.82$ \\
\hline & B1B2/B2B2 & 292 & $4.95 \pm 0.96$ & $1.06(0.88)$ & $1.54 \pm 0.29$ & $2.73 \pm 0.89$ & $0.66 \pm 0.36$ \\
\hline$F$ & - & - & 4.713 & -1.007 & 12.514 & 1.732 & 0.596 \\
\hline$P$ & - & - & 0.030 & 0.314 & 0.000 & 0.189 & 0.441 \\
\hline
\end{tabular}

TC, total cholesterol; TG, triglyceride; HDL-C, high-density lipoprotein cholesterol; LDL-C, low-density lipoprotein cholesterol. The value of triglyceride was presented as median (interquartile range). The difference among/between the genotypes was determined by the Kruskal-Wallis test or Wilcoxon-Mann-Whitney test ${ }^{a} P<0.05$ in comparison with B1B1 genotype of same group; ${ }^{b} P<0.05$ in comparison with the same genotype of non-LG

It has been established that HDL-C is an independent risk factor for CHD [43]. A growing body of evidences demonstrate that elevated levels of HDL-C may reduce CHD risk and thus contribute to longer life expectancy
[13]. We also found higher HDL-C and LDL-C levels in the long-lived subjects as compared to general populations. Moreover, this raised HDL-C was associated with B2 allele and B2B2 genotype, which was consistent with

Table 4 Comparison of clinical characteristics and serum lipid levels among the genotypes stratified by gender in overall population

\begin{tabular}{|c|c|c|c|c|c|}
\hline Parameter & B1B1 & B1B2 & B2B2 & $F$ & $P$ \\
\hline Male/n & 166 & 224 & 47 & - & - \\
\hline Age (years) & $70.15 \pm 21.11$ & $68.85 \pm 21.37$ & $69.62 \pm 23.38$ & 0.177 & 0.838 \\
\hline Body mass index $\left(\mathrm{kg} / \mathrm{m}^{2}\right)$ & $21.48 \pm 3.35$ & $21.58 \pm 3.43$ & $21.17 \pm 4.04$ & 0.285 & 0.752 \\
\hline Systolic blood pressure $(\mathrm{mmHg})$ & $146.767 \pm 26.80$ & $142.51 \pm 27.92$ & $144.98 \pm 26.29$ & 1.169 & 0.312 \\
\hline Diastolic blood pressure $(\mathrm{mmHg})$ & $88.76 \pm 12.64$ & $85.90 \pm 11.89$ & $88.04 \pm 14.55$ & 2.615 & 0.074 \\
\hline Total cholesterol (mmol/L) & $4.937 \pm 1.09$ & $4.88 \pm 1.00$ & $5.36 \pm 1.12$ & 4.237 & 0.015 \\
\hline Triglyceride (mmol/L) & $1.08(0.67)$ & $0.95(0.78)$ & $1.18(0.74)$ & 7.329 & 0.026 \\
\hline $\mathrm{HDL}-\mathrm{C}(\mathrm{mmol} / \mathrm{L})$ & $1.47 \pm 0.30$ & $1.57 \pm 0.33$ & $1.71 \pm 0.36$ & 10.803 & 0.000 \\
\hline LDL-C (mmol/L) & $2.85 \pm 0.96$ & $2.74 \pm 0.94$ & $2.86 \pm 0.93$ & 0.788 & 0.455 \\
\hline HDL-C/LDL-C & $0.66 \pm 0.89$ & $0.67 \pm 0.34$ & $0.68 \pm 0.33$ & 0.010 & 0.990 \\
\hline Female/n & 227 & 286 & 71 & - & - \\
\hline Age (years) & $73.93 \pm 21.91$ & $78.76 \pm 19.30$ & $79.56 \pm 18.62$ & 4.249 & 0.015 \\
\hline Body mass index $\left(\mathrm{kg} / \mathrm{m}^{2}\right)$ & $21.24 \pm 4.52$ & $20.47 \pm 3.30$ & $21.59 \pm 3.70$ & 3.777 & 0.023 \\
\hline Systolic blood pressure $(\mathrm{mmHg})$ & $150.42 \pm 29.39$ & $154.15 \pm 33.03$ & $154.17 \pm 32.08$ & 0.972 & 0.379 \\
\hline Diastolic blood pressure $(\mathrm{mmHg})$ & $88.18 \pm 12.45$ & $86.59 \pm 13.09$ & $88.35 \pm 12.78$ & 1.188 & 0.305 \\
\hline Total cholesterol (mmol/L) & $4.99 \pm 0.92$ & $5.12 \pm 0.96$ & $4.88 \pm 0.93$ & 2.392 & 0.092 \\
\hline Triglyceride (mmol/L) & $1.07(0.80)$ & $1.00(0.49)$ & $1.00(0.60)$ & 2.739 & 0.254 \\
\hline $\mathrm{HDL}-\mathrm{C}(\mathrm{mmol} / \mathrm{L})$ & $1.50 \pm 0.30$ & $1.59 \pm 0.35$ & $1.62 \pm 0.29$ & 5.739 & 0.003 \\
\hline LDL-C (mmol/L) & $2.87 \pm 0.85$ & $3.02 \pm 0.86$ & $2.74 \pm 0.84$ & 3.810 & 0.023 \\
\hline HDL-C/LDL-C & $0.57 \pm 0.23$ & $0.58 \pm 0.29$ & $0.66 \pm 0.29$ & 2.954 & 0.053 \\
\hline
\end{tabular}

$\mathrm{HDL}-\mathrm{C}$, high-density lipoprotein cholesterol; LDL-C, low-density lipoprotein cholesterol. The value of triglyceride was presented as median (interquartile range), the difference among the genotypes was determined by the Kruskal-Wallis Test. 
Table 5 Comparison of clinical characteristics and serum lipid Levels among genotypes stratified by gender in LG

\begin{tabular}{|c|c|c|c|c|c|}
\hline Parameter & B1B1 & B1B2 & B2B2 & $F$ & $P$ \\
\hline Male/n & 70 & 91 & 23 & - & - \\
\hline Age (years) & $93.61 \pm 3.43$ & $93.17 \pm 2.68$ & $92.61 \pm 2.73$ & 1.081 & 0.341 \\
\hline Body mass index $\left(\mathrm{kg} / \mathrm{m}^{2}\right)$ & $20.82 \pm 3.70$ & $20.30 \pm 3.30$ & $20.30 \pm 5.05$ & 0.426 & 0.654 \\
\hline Systolic blood pressure $(\mathrm{mmHg})$ & $164.79 \pm 26.08$ & $162.59 \pm 27.50$ & $161.22 \pm 23.48$ & 0.213 & 0.808 \\
\hline Diastolic blood pressure $(\mathrm{mmHg})$ & $88.60 \pm 13.55$ & $89.14 \pm 13.73$ & $88.70 \pm 13.65$ & 0.034 & 0.967 \\
\hline Total cholesterol (mmol/L) & $4.97 \pm 1.07$ & $4.96 \pm 1.09$ & $5.30 \pm 1.05$ & 0.96 & 0.385 \\
\hline Triglyceride (mmol/L) & $0.93(0.37)$ & $0.91(0.32)$ & $1.03(0.41)$ & 5.925 & 0.052 \\
\hline $\mathrm{HDL}-\mathrm{C}(\mathrm{mmol} / \mathrm{L})$ & $1.52 \pm 0.33$ & $1.65 \pm 0.39$ & $1.73 \pm 0.44$ & 3.768 & 0.025 \\
\hline LDL-C (mmol/L) & $2.98 \pm 0.93$ & $2.89 \pm 0.94$ & $3.01 \pm 0.96$ & 0.244 & 0.784 \\
\hline HDL-C/LDL-C & $0.66 \pm 0.89$ & $0.67 \pm 0.34$ & $0.68 \pm 0.33$ & 0.010 & 0.990 \\
\hline Female/n & 117 & 179 & 43 & - & - \\
\hline Age (years) & $94.07 \pm 3.30$ & $92.99 \pm 2.86$ & $93.65 \pm 3.28$ & 4.432 & 0.013 \\
\hline Body mass index $\left(\mathrm{kg} / \mathrm{m}^{2}\right)$ & $19.86 \pm 3.25$ & $19.89 \pm 3.24$ & $21.44 \pm 4.25$ & 3.970 & 0.020 \\
\hline Systolic blood pressure $(\mathrm{mmHg})$ & $167.16 \pm 27.44$ & $167.87 \pm 29.84$ & $168.47 \pm 28.78$ & 0.038 & 0.962 \\
\hline Diastolic blood pressure $(\mathrm{mmHg})$ & $91.08 \pm 13.38$ & $88.04 \pm 13.40$ & $91.84 \pm 13.21$ & 2.526 & 0.082 \\
\hline Total cholesterol (mmol/L) & $5.27 \pm 0.94$ & $5.16 \pm 0.98$ & $5.10 \pm 0.96$ & 0.645 & 0.525 \\
\hline Triglyceride (mmol/L) & $1.09(0.76)$ & $1.00(0.51)$ & $0.95(0.41)$ & 2.923 & 0.232 \\
\hline $\mathrm{HDL}-\mathrm{C}(\mathrm{mmol} / \mathrm{L})$ & $1.55 \pm 0.30$ & $1.62 \pm 0.37$ & $1.64 \pm 0.30$ & 1.603 & 0.203 \\
\hline LDL-C (mmol/L) & $3.19 \pm 0.77$ & $3.07 \pm 0.86$ & $2.97 \pm 0.84$ & 1.255 & 0.287 \\
\hline HDL-C/LDL-C & $0.57 \pm 0.23$ & $0.58 \pm 0.29$ & $0.66 \pm 0.29$ & 2.954 & 0.053 \\
\hline
\end{tabular}

HDL-C, high-density lipoprotein cholesterol; LDL-C, low-density lipoprotein cholesterol. The value of triglyceride was presented as median (interquartile range), the difference among the genotypes was determined by the Kruskal-Wallis Test.

some previous reports $[12,14,34,44-46]$, but not others $[17,47]$. It is widely accepted that B2 allele carriers exhibit lower CETP levels and/or activity, leading to a dysfunction of the reverse cholesterol transport, causing an accumulation of cholesterol ester in HDL style and thus increasing the levels of HDL-C. The mechanism by which TaqIB polymorphism may affect CETP activity or HDL-C levels is not well known. Because this

Table 6 Comparison of clinical characteristics and serum lipid levels among genotypes stratified by gender in non-LG

\begin{tabular}{|c|c|c|c|c|c|}
\hline Parameter & B1B1 & B1B2 & B2B2 & $F$ & $P$ \\
\hline Male/n & 96 & 133 & 24 & - & - \\
\hline Age (years) & $53.04 \pm 8.00$ & $52.21 \pm 8.95$ & $47.58 \pm 7.11$ & 4.044 & 0.019 \\
\hline Body mass index $\left(\mathrm{kg} / \mathrm{m}^{2}\right)$ & $21.96 \pm 2.99$ & $22.46 \pm 3.25$ & $22.00 \pm 2.62$ & 0.808 & 0.447 \\
\hline Systolic blood pressure $(\mathrm{mmHg})$ & $133.63 \pm 18.41$ & $128.77 \pm 18.25$ & $129.42 \pm 18.40$ & 2.022 & 0.135 \\
\hline Diastolic blood pressure $(\mathrm{mmHg})$ & $88.88 \pm 11.99$ & $83.68 \pm 9.89$ & $87.42 \pm 15.63$ & 6.040 & 0.003 \\
\hline Total cholesterol (mmol/L) & $4.90 \pm 1.11$ & $4.82 \pm 0.94$ & $5.43 \pm 1.21$ & 3.531 & 0.031 \\
\hline Triglyceride (mmol/L) & $1.22(0.76)$ & $1.16(1.02)$ & $1.28(1.38)$ & 3.231 & 0.199 \\
\hline $\mathrm{HDL}-\mathrm{C}(\mathrm{mmol} / \mathrm{L})$ & $1.44 \pm 0.27$ & $1.52 \pm 0.27$ & $1.69 \pm 0.27$ & 8.180 & 0.000 \\
\hline LDL-C (mmol/L) & $2.76 \pm 0.99$ & $2.63 \pm 0.93$ & $2.71 \pm 0.90$ & 0.485 & 0.616 \\
\hline $\mathrm{HDL}-\mathrm{C} / \mathrm{LDL}-\mathrm{C}$ & $0.75 \pm 1.16$ & $0.68 \pm 0.37$ & $0.72 \pm 0.34$ & 0.196 & 0.822 \\
\hline Female/n & 110 & 107 & 28 & - & - \\
\hline Age (years) & $52.51 \pm 9.27$ & $54.95 \pm 8.56$ & $57.93 \pm 8.97$ & 4.792 & 0.009 \\
\hline Body mass index $\left(\mathrm{kg} / \mathrm{m}^{2}\right)$ & $22.71 \pm 5.18$ & $21.45 \pm 3.18$ & $21.82 \pm 2.70$ & 2.562 & 0.079 \\
\hline Systolic blood pressure (mmHg) & $132.62 \pm 19.22$ & $131.21 \pm 24.28$ & $132.21 \pm 23.53$ & 0.112 & 0.894 \\
\hline Diastolic blood pressure $(\mathrm{mmHg})$ & $85.09 \pm 10.59$ & $84.15 \pm 12.22$ & $83.00 \pm 10.15$ & 0.446 & 0.641 \\
\hline Total cholesterol (mmol/L) & $4.69 \pm 0.79$ & $5.05 \pm 0.92$ & $4.55 \pm 0.80$ & 6.635 & 0.002 \\
\hline Triglyceride (mmol/L) & $1.01(0.95)$ & $0.98(0.45)$ & $1.18(1.41)$ & 0.975 & 0.614 \\
\hline $\mathrm{HDL}-\mathrm{C}(\mathrm{mmol} / \mathrm{L})$ & $1.45 \pm 0.30$ & $1.54 \pm 0.30$ & $1.60 \pm 0.28$ & 3.788 & 0.024 \\
\hline LDL-C (mmol/L) & $2.54 \pm 0.80$ & $2.93 \pm 0.84$ & $2.38 \pm 0.70$ & 8.591 & 0.000 \\
\hline HDL-C/LDL-C & $0.64 \pm 0.28$ & $0.60 \pm 0.35$ & $0.74 \pm 0.33$ & 2.270 & 0.106 \\
\hline
\end{tabular}

HDL-C, high-density lipoprotein cholesterol; LDL-C, low-density lipoprotein cholesterol. The value of triglyceride was presented as median (interquartile range), the difference among the genotypes was determined by the Kruskal-Wallis Test. 
Table 7 Correlation between serum lipid parameters and the CETP TaqIB polymorphism in LG and non-LG

\begin{tabular}{|c|c|c|c|c|c|c|}
\hline Lipid & Relative factor & Unstandardized coefficient & Standard error & Standardized coefficient & $t$ & $P$ \\
\hline \multicolumn{7}{|l|}{ LG plus non-LG } \\
\hline $\mathrm{HDL}-\mathrm{C}$ & Genotype & 0.080 & 0.015 & 0.160 & 5.316 & 0.000 \\
\hline \multicolumn{7}{|l|}{ LG } \\
\hline $\mathrm{TG}$ & Genotype & -0.064 & 0.029 & -0.093 & -2.191 & 0.029 \\
\hline $\mathrm{HDL}-\mathrm{C}$ & Genotype & 0.074 & 0.023 & 0.138 & 3.219 & 0.001 \\
\hline HDL-C/LDL-C & Genotype & 0.054 & 0.016 & 0.149 & 3.464 & 0.001 \\
\hline \multicolumn{7}{|l|}{ Non-LG } \\
\hline $\mathrm{TC}$ & Genotype & 0.132 & 0.065 & 0.089 & 2.030 & 0.043 \\
\hline $\mathrm{HDL}-\mathrm{C}$ & Genotype & 0.084 & 0.019 & 0.189 & 4.435 & 0.000 \\
\hline
\end{tabular}

polymorphism located in an intron of the CETP gene which is unlikely to exhibit any functional effect. Given the reported associations of the B2 allele with increased CETP mass and/or activity, the most putative explanation is that this polymorphism is in linkage disequilibrium with some unknown functional mutations in the regulatory region of the CETP gene which might interact with each other to determine the HDL-C levels $[45,48]$.

Some investigators suggested that TaqIB polymorphisms were solely associated with HDL-C levels, without being influenced by factors such as smoking, alcohol consumption and BMI [49], but most researchers believed that the association between TaqIB polymorphisms and HDL-C levels might be greatly affected by dietary habits, smoking, obesity, gender, and ethnic groups, etc. [34,50-52]. In the present study, we also showed that the association of CETP TaqIB polymorphism and serum lipid profiles is different between LG and non-LG, or between males and females in the Chinese Bama Zhuang population. The subjects with B2B2 and B1B2 genotyes in LG had higher HDL-C levels and HDL-C/LDL-C ratio than the subjects with B1B1 genotye, whereas the B2 allele carriers in non-LG had lower $\mathrm{TC}$ and higher HDL-C levels than the B2 allele noncarriers. The levels of HDL-C in LG were different among the genotypes in males but not in females. The levels of HDL-C in non-LG were different among the genotypes in males, whereas the levels of TC, HDL-C and LDL-C were different among the genotypes in females. The reason for this discrepancy is not well known. Thus, to better define the exact association of TaqIB polymorphisms with serum HDL-C levels and CHD, further studies are required in large populations.

\section{Conclusion}

The current study shows that the genotypic and allelic frequencies of CETP TaqIB polymorphism were not different between LG and non-LG, but the association of CETP TaqIB polymorphism and serum lipid profiles is different between the two groups in the Chinese Bama
Zhuang population. The B2 allele and B2B2 genotype were associated with high HDL-C levels. Thus, CETP TaqIB polymorphism might be one of the longevityrelated genes in this population.

\section{Acknowledgements}

We especially thank all of those who donated samples. This study was supported by the National Natural Science Foundation of China (No. $30860126,31160209)$ and the Natural Science Foundation of Guangxi (No. GKQ0991033, GKZ0728160).

\section{Author details}

${ }^{1}$ Department of Cardiology, Institute of Cardiovascular Diseases, the First Affiliated Hospital, Guangxi Medical University, 22 Shuangyong Road, Nanning 530021, Guangxi, People's Republic of China. ${ }^{2}$ Department of Pathophysiology, School of Premedical Sciences, Guangxi Medical University, Nanning 530021, Guangxi, People's Republic of China. ${ }^{3}$ Department of Neurology, Jiangbin Hospital of Guangxi Zhuang Autonomous Region, 85 Hedi Road, Nanning 530021, Guangxi, People's Republic of China.

\section{Authors' contributions}

SLP participated in the design, undertook genotyping, and drafted the manuscript. FW, CWL, JHP, XQL, SHL, HYW and LJH helped with genotyping. $\mathrm{ZPL}, \mathrm{CYH}, \mathrm{HL}$ and GFP took part in the epidemiological survey and collected the samples. RXY conceived the study, participated in the design, carried out the epidemiological survey, collected the samples, and helped to draft the manuscript. All authors read and approved the final manuscript.

\section{Competing interests}

The authors declare that they have no competing interests.

Received: 21 January 2012 Accepted: 15 February 2012

Published: 15 February 2012

\section{References}

1. Tall A: Plasma lipid transfer proteins. Annu Rev Biochem 1995, 64:235-257.

2. Bruce C, Sharp DS, Tall AR: Relationship of HDL and coronary heart disease to a common amino acid polymorphism in the cholesteryl ester transfer protein in men with and without hypertriglyceridemia. J Lipid Res 1998, 39:1071-1078.

3. Bruce C, Chouinard RA Jr: Tall AR: Plasma lipid transfer proteins, high density lipoproteins, and reverse cholesterol transport. Annu Rev Nutr 1998, 18:297-330.

4. Drayna D, Jarnagin AS, McLean J, Henzel W, Kohr W, Fielding C, Lawn R: Cloning and sequencing of human cholesteryl ester transfer protein cDNA. Nature 1987, 27:632-634

5. Inazu A, Brown ML, Hesler CB, Agellon LB, Koizumi J, Takata K, Maruhama Y, Mabuchi H, Tall AR: Increased high-density lipoprotein levels caused by a common cholesteryl-ester transfer protein gene mutation. N Engl J Med 1990, 323:1234-1238.

6. Agerholm-Larsen B, Tybjaerg-Hansen A, Schnohr P, Steffensen R, Nordestgaard BG: Common cholesteryl ester transfer protein mutations, 
decreased HDL cholesterol, and possible decreased risk of ischemic heart disease. The Copenhagen City Heart Study. Circulation 2000, 102:2197-2203

7. Frisdal E, Klerkx AH, Le Goff W, Tanck MW, Lagarde JP, Jukema JW, Kastelein JJ, Chapman MJ, Guerin M: Functional interaction between -629 C/A, $-971 \mathrm{G} / \mathrm{A}$ and $-1337 \mathrm{C} / \mathrm{T}$ polymorphisms in the CETP gene is a major determinant of promoter activity and plasma CETP concentration in the REGRESS Study. Hum Mol Genet 2005, 14:2607-2618.

8. Yijiang $Z$, Ruixing $Y$, Yiyang $L$, Yaju $D$, Shangling $P$, Weixiong $L$, Dezhai $Y$ : Association of TaqIB polymorphism in the cholesteryl ester transfer protein gene with serum lipid levels in the Guangxi Hei Yi Zhuang and Han populations. J Investig Med 2008, 56:847-857.

9. Freeman DJ, Packard CJ, Shepherd J, Gaffney D: Polymorphismsin the gene coding for cholesteryl ester transferprotein are related to plasma high-density lipoprotein cholesterol and transfer protein activity. Clin Sci 1990, 79:575-581.

10. McPherson R, Grundy SM, Guerra R, Cohen JC: Allelic variation in the gene encoding the cholesteryl ester transfer protein is associated with variation in the plasma concentrations of cholesteryl ester transfer protein. J Lipid Res 1996, 37:1743-1748.

11. Thompson A, Di Angelantonio E, Sarwar N, Erqou S, Saleheen D, Dullaart RP, Keavney B, Ye Z, Danesh J: Association of cholesteryl ester transfer protein genotypes with CETP mass and activity, lipid levels, and coronary risk. JAMA 2008, 299:2777-2788.

12. Boekholdt SM, Kuivenhoven JA, Hovingh GK, Jukema JW, Kastelein JJ, van Tol A: CETP gene variation: relation to lipid parameters and cardiovascular risk. Curr Opin Lipidol 2004, 15:393-398.

13. Arai $\mathrm{Y}$, Hirose $\mathrm{N}$ : Aging and $\mathrm{HDL}$ metabolism in elderly people more than 100 years old. J Atheroscler Thromb 2004, 11:246-252.

14. Kolovou G, Stamatelatou M, Anagnostopoulou K, Kostakou P, Kolovou V, Mihas C, Vasiliadis I, Diakoumakou O, Mikhailidis DP, Cokkinos DV: Cholesteryl ester transfer protein gene polymorphisms and longevity syndrome. Open Cardiovasc Med J 2010, 4:14-19.

15. Nikkilä M, Heikkinen J: Serum cholesterol, high-density lipoprotein cholesterol and five-year survival in elderly people. Age Ageing 1990, 19:119-124.

16. Nagano M, Yamashita S, Hirano K, Takano M, Maruyama T, Ishihara M, Sagehashi Y, Kujiraoka T, Tanaka K, Hattori H, Sakai N, Nakajima N, Egashira T, Matsuzawa Y: Molecular mechanisms of cholesteryl ester transfer protein deficiency in Japanese. J Atheroscler Thromb 2004, 11:110-121.

17. Arai Y, Hirose N, Yamamura K, Nakazawa S, Shimizu K, Takayama M, Ebihara Y, Homma S, Gondo Y, Masui Y, Inagaki H: Deficiency of choresteryl ester transfer protein and gene polymorphisms of lipoprotein lipase and hepatic lipase are not associated with longevity. J Mol Med (Berl) 2003, 81:102-109.

18. Xiao $Z, X u Q$, Yuan $Y$ : Solving the mystery of the status and longevity of centenarians in Bama. Chin J Popul Sci 1996, 8:385-394.

19. Pan S, Chen J, Yin R, Liu C, Huang L, Chen W, Luo X, Chen J, Huang B, Luo $Y$ : The association of mitochondrial DNA haplogroup with human longevity in Guangxi Bama area. Chin J Geriatr 2006, 25:362-363.

20. Tokui N, Minari Y, Kusunoki K, Yoshimura T, Yamamoto T, Minagawa M: Evaluation of dietary intake using carbon and nitrogen isotope analysis of human hair of Chinese living in southern part of China. J UOEH 2000 22:219-228.

21. Yang J: On the Bama longevity zone and the local environment for survival. Chin J Popul Sci 1994, 6:333-343.

22. Liang JY, Hu CY, Lu ZP, Li ZJ, Huang PY, Li BX, Yang YY: LU Y, Pang GF, Wei Q, Li L, Yang Z: Investigation of risk factors associated with cardiocerebrovascular diseases in longevity elderly population in Bama. Chin J Cardiovasc Med 2008, 13:349-352.

23. Chen J, Li H, Qin ZD, Liu WH, Lin WX, Yin RX, Jin L, Pan SL: Y-chromosome genotyping and genetic structure of Zhuang populations. Yi Chuan Xue Bao 2006, 33:1060-1072.

24. Li H, Wen B, Chen SJ, Su B, Pramoonjago P, Liu Y, Pan S, Qin Z, Liu W, Cheng X, Yang N, Li X, Tran D, Lu D, Hsu MT, Deka R, Marzuki S, Tan CC, Jin L: Paternal genetic affinity between western Austronesians and Daic populations. BMC Evol Bio 2008, 8:146.

25. Long GF, Pan SL, Lin WX, Chen JC, Huang BG, Luo Y: A study on DNA polymorphism of HLA-DQA1 and DQB1 loci in Zhuang nationality in
Bama county and its association with human longevity. Chin J Geriatr 2000, 19:289-291.

26. Pan $S L$, Liu CW, Zhou XL, Huang LJ, Lin WX, Long GF, Lu ZP, Hu CY, Chen JC: Polymorphism of HLA-DRB1 locus of the Zhuang longevous elderly in Bama County of Guangxi. Chin J Gerontol 2005, 25:365-367.

27. Hu CY, Zheng CG, Lu ZP, Yang Z, Liang JY, Wei Y, Qu YC, Wei JX, Chen JC The study of relation between blood pressure and apolipoprotein $\mathrm{E}$ genotypes in long-lived elderly in Bama area of Guangxi. Chin J Geriatr Heart Brain Vessel Dis 2007, 9:11-13.

28. Chen WC, Pan SL, Lin WX, Chen J, Luo XQ: The research of p53 gene polymorph ism $\mathrm{s}$ in Zhuang nationality centenarians of Guangxi Bama area. Chin J Gerontol 2008, 28:265-267.

29. Liu CW, Luo XQ, Lin WX, Yin RX, Lu ZP, Pan SL: Polymorphism of the transforming growth factor- $\beta 1$ gene of Zhuang population in Guangxi Bama area and Hezhou area. Shandong Med J 2009, 49:17-19.

30. Ruixing $Y$, Jiagiang $D$, Dezhai $Y$, Weixiong $L$, Shangling $P$, Jinzhen $W$ Jiandong $H$, Xiuyan L: Effects of demographic characteristics, healthrelated behaviors and lifestyle factors on the prevalence of hypertension for the middle-aged and elderly in the Guangxi Hei Yi Zhuang and Han populations. Kidney Blood Press Res 2006, 29:312-320.

31. Cooperative Meta-analysis Group of China Obesity Task Force: Predictive values of body mass index and waist circumference to risk factors of related diseases in Chinese adult population. Chin J Epidemiol 2002, 23:5-10.

32. Ruixing $Y$, Yuming $C$, Shangling $P$, Fengbing $H$, Tangwei $L$, Dezhai $Y$, Jinzhen $W$, Limei $Y$, Weixiong $L$, Rongshan $L$, Jiandong $H$ : Effects of demographic, dietary, and other lifestyle factors on the prevalence of hyperlipidemia in Guangxi Hei Yi Zhuang and Han populations. Eur J Cardiovasc Prev Rehabil 2006, 13:977-984.

33. Miller SA, Dykes DD, Polesky HF: A simple salting outprocedure for extracting DNA from human nucleated cells. Nucleic Acids Res 1988, 16:1215.

34. Zhou Y, Yin R, Deng Y, Li Y, Wu J: Interactions between alcohol intake and the polymorphism of rs708272 on serum high-density lipoprotein cholesterol levels in the Guangxi Hei Yi Zhuang population. Alcohol 2008, 42:583-591.

35. Fumeron F, Betoulle D, Luc G, Behague I, Ricard S, Poirier O, Jemaa R, Evans A, Arveiler D, Marques-Vidal P, Bard JM, Fruchart JC, Ducimetiere P, Apfelbaum M, Cambien F: Alcohol intake modulates the effect of a polymorphism of the cholesteryl ester transfer protein gene on plasma high density lipoprotein and the risk of myocardial infarction. J Clin Invest 1995, 96:1664-1671.

36. Zhao Q, Pan S, Qin Z, Cai X, Lu Y, Farina SE, Liu C, Peng J, Xu J, Yin R, Li S, Li J, Li H: Gene flow between Zhuang and Han populations in the ChinaVietnam borderland. J Hum Genet 2010, 55:774-776.

37. Zheng $\mathrm{KQ}$, Zhang $\mathrm{SZ}$, He $Y$, Zhang $L$, Zhang $\mathrm{KL}$, Huang DJ, Sun $Y$ : Association between cholesteryl ester transfer protein gene polymorphisms and variations in lipid levels in patients with coronary heart disease. Chin Med J (Engl) 2004, 117:1288-1292.

38. Thu NN, Mai TT, Ohmori R, Kuroki M, Van Chuyen N, Hung NT, Kawakami M, Kondo K: Effect of the cholesteryl ester transfer protein genotypes on plasma lipid and lipoprotein levels in Vietnamese children. Pediatr Res 2005, 58:1249-1253.

39. Hong SH, Kim YR, Song J, Kim JQ: Genetic variations of cholesterol ester transfer protein gene in Koreans. Hum Biol 2001, 73:815-821.

40. Kondo I, Berg K, Drayna D, Lawn R: DNA polymorphism at the locus for human cholesteryl ester transfer protein (CETP) is associated with high density lipoprotein cholesterol and apolipoprotein levels. Clin Genet 1989, 35:49-56.

41. Kark JD, Sinnreich R, Leitersdorf E, Friedlander Y, Shpitzen S, Luc G: TaqIB CETP polymorphism, plasma CETP, lipoproteins, apolipoproteins and sex differences in a Jewish population sample characterized by low HDLcholesterol. Atherosclerosis 2000, 151:509-518.

42. Meguro S, Takei I, Murata M, Hirose $H$, Takei N, Mitsuyoshi $Y$, Ishii $K$, Oguchi S, Shinohara J, Takeshita E, Watanabe K, Saruta T: Cholesteryl ester transfer protein polymorphism associated with macroangiopathy in Japanese patients with type 2 diabetes. Atherosclerosis 2001, 156:151-156.

43. Packard CJ, Saito Y: Non-HDL cholesterol as a measure of atherosclerotic risk. I Atheroscler Thromb 2004 , 11:6-14.

44. Brousseau ME, O'Connor JJ Jr, Ordovas JM, Collins D, Otvos JD, Massov T, McNamara JR, Rubins HB, Robins SJ, Schaefer EJ: Cholesteryl ester transfer protein Taql B2B2 genotype is associated with higher HDL cholesterol 
levels and lower risk of coronary heart disease end points in men with HDL deficiency: Veterans Affairs HDL Cholesterol Intervention Trial. Arterioscler Thromb Vasc Biol 2002, 22:1148-1154.

45. Ordovas JM, Cupples LA, Corella D, Otvos JD, Osgood D, Martinez A, Lahoz C, Coltell O, Wilson PW, Schaefer EJ: Association of cholesteryl ester transfer protein-TaqIB polymorphism with variations in lipoprotein subclasses and coronary heart disease risk: the Framingham study. Arterioscler Thromb Vasc Biol 2000, 20:1323-1329.

46. Ozsait B, Kömürcü Bayrak E, Poda M, Can G, Hergenç G, Onat A Humphries SE, Erginel Unaltuna N: CETP TaqIB polymorphism in Turkish adults: association with dyslipidemia and metabolic syndrome. Anado/u Kardiyol Derg 2008, 8:324-330.

47. Kuivenhoven JA, Jukema JW, Zwinderman AH, de Knijff $P, M c P h e r s o n ~ R$, Bruschke AV, Lie Kl, Kastelein JJ: The role of a common variant of the cholesteryl ester transfer protein gene in the progression of coronary atherosclerosis. The Regression Growth Evaluation Statin Study Group. N Engl J Med 1998, 338:86-93

48. Junyent M, Lee YC, Smith CE, Arnett DK, Tsai MY, Kabagambe EK, Straka RJ, Province M, An P, Lai CQ, Parnell LD, Shen J, Borecki I, Ordovas JM: The effect of a novel intergenic polymorphism (rs11774572) on HDLcholesterol concentrations depends on TaqIB polymorphism in the cholesterol ester transfer protein gene. Nutr Metab Cardiovasc Dis 2010, 20:34-40.

49. Corella D, Sáiz C, Guillén M, Portolés O, Mulet F, González Jl, Ordovás JM: Association of TaqIB polymorphism in the cholesteryl ester transfer protein gene with plasma lipid levels in a healthy Spanish population. Atherosclerosis 2000, 152:367-376.

50. Freeman DJ, Griffin BA, Holmes AP, Lindsay GM, Gaffney D, Packard CJ, Shepherd J: Regulation of plasma HDL cholesterol and subfraction distribution by genetic and environmental factors. Associations between the Taql B RFLP in the CETP gene and smoking and obesity. Arterioscler Thromb 1994, 14:336-344.

51. Corella D, Carrasco P, Amiano P, Arriola L, Chirlaque MD, Huerta JM, Martínez C, Martinez-Camblor P, Molina E, Navarro C, Quirós JR, Rodríguez L, Sánchez MJ, Ortega-Azorín C, Ros E, Sala N, González CA, Moreno C: Common cholesteryl ester transfer protein gene variation related to high-density lipoprotein cholesterol is not associated with decreased coronary heart disease risk after a 10-year follow-up in a Mediterranean cohort: Modulation by alcohol consumption. Atherosclerosis 2010, 211:531-538.

52. Dedoussis GV, Panagiotakos DB, Louizou E, Mantoglou I, Chrysohoou C, Lamnisou K, Pitsavos C, Stefanadis C: Cholesteryl ester-transfer protein (CETP) polymorphism and the association of acute coronary syndromes by obesity status in Greek subjects: the CARDIO2000-GENE study. Hum Hered 2007, 63:155-161.

doi:10.1186/1476-511X-11-26

Cite this article as: Pan et al:: Cholesteryl ester transfer protein TaqIB polymorphism and its association with serum lipid levels and longevity in Chinese Bama Zhuang population. Lipids in Health and Disease 2012 11:26.

\section{Submit your next manuscript to BioMed Central and take full advantage of:}

- Convenient online submission

- Thorough peer review

- No space constraints or color figure charges

- Immediate publication on acceptance

- Inclusion in PubMed, CAS, Scopus and Google Scholar

- Research which is freely available for redistribution 